\title{
Literature Review \\ Interpreting Islamic Doctrine as the Religion of Liberation in Education (Considering the Thoughts of Asghar Ali Engineer)
}

\author{
${ }^{* 1}$ Karwadi, ${ }^{2}$ Aninditya Sri Nugraheni, ${ }^{3}$ Shindy Lestari \\ Submitted: 07/09/2021 \\ Revised: $15 / 10 / 2021$ \\ Accepted: 13/11/2021 \\ *11Universitas Islam Negeri Sunan Kalijaga Yogyakarta, Indonesia, karwadi_17@yahoo.co.id \\ ${ }^{2}$ Universitas Islam Negeri Sunan Kalijaga Yogyakarta, Indonesia, aninditya.nugraheni@uin-suka.ac.id \\ ${ }^{3}$ Universitas Islam Negeri Sunan Kalijaga Yogyakarta, Indonesia, shindylestari4@gmail.com
}

How to cite this article: Karwadi, Nugraheni, A.S. \& Lestari, S. 2021. Interpretating Islamic doctrine as the religion of liberation in education (Considering the thought of Asghar Ali engineer). International Journal of Education, Language and Religion. 3(2), 55-64. doi: 10.35308/ijelr.v3i2.4387

\begin{abstract}
Education must be returned to its original khittah, that is, to humanize man with all the potential he has. In this framework, important efforts in the Islamic liberation must be the spirit and foundation of ontological, epistemological as well as axiological education. Among the contemporary Islamic thoughts that give awareness that Islam has the power of liberation is the Asghar Ali Engineer which is derived primarily from the Qur'an and Sunnah. This finding can interpret the doctrine of Islam as a religion of liberation in education that weighs from the thoughts of Asghar Ali Engineer who has relevance and urgency. The results of this study explain about alternative solutions to the problems Islamic education in the era of globalization, namely: 1) greater attention to the reality of living in the world, can be used as a foundation for compiling the Islamic education curriculum. 2) Fight against the pro status quo. Islamic education should be based on the spirit of respecting humans as beings thinking, conscious, potentially and equipped with the right to determine their own life choices. 3) Side with marginalized communities and encourage them to actively participate. 4) Liberation theology emphasizes on the problem of praxis rather than on abstract-speculative thoughts. So that the nuances of Islamic education are quite felt is the pressure on the rational, intellectual, ethical aspects, very few that enter the applied area, skills or technology as one of the meanings that can be taken from the spirit of Islamic liberation theology.
\end{abstract}

\section{Keywords}

islamic doctrine; liberation in education; Asghar Ali Engineer thought

\section{Introduction}

Islam, by many chroniclers, is seen as liberating force, a liberating force of mankind (Rakhmat, 1994: 65). Judging from the history of the birth of Islam, the nuances of liberation contained in Islamic teachings are so felt. Islam did not come to legitimize the status quo; instead, it was born in the sociopolitical-cultural context of Mecca which limped to turn it into an exploitative, just and egalitarian order 
and free humanity from all forms of oppression. In this regard, Sayyid Qutub asserts that Islam is an active revolutionary aqidah, which is a proclamation of human liberation from human slavery (Qutub, 1994: 143; Al-Effendi, 1994: 69). According to Siswanto (2019) that Islam is a religion with a vision of humanity.

As an instrument of human liberation in life, the presence of Islam is meant to humanize social reality. Islam is not merely to give an interpretation of the reality, but rather to elevate it to a better level. Thus, Islamic dialogue with social reality becomes condition sine qua non.

Analogizing Islam with social reality is not only necessary on the plains of discourse, but more than that must come to a praxis state. In this framework it is necessary to open the widest space for the struggle of discourse, while also encouraging the development of social praxis of Muslims to humanize reality. One of the social realities of Muslims that needs to continue to get a response is the aspect of education.

Education in general can be understood as the process of human social maturation towards an ideal state. In other words, education is the process of humanizing people. The meaning contained in it concerns the purpose of maintaining and developing human potential or resources towards the formation of the whole human being (Achmadi, 1992: 16).

The appreciation for freedom to develop and think forward is of course very large, considering that humans are creatures who think and have consciousness. The practice of education must always refer to the existence of man itself. From there will be a democratic educational mechanism and oriented to humanizing humans. Thus, education is not a transfer of knowledge alone, but helps learners to be able to develop their potential (Hartoko, 1985: 36).

In reality, the practice of education that occurs is more visible as teaching indoctrination and becomes a tool of hegemony for the ruling elite. Admittedly, education today cannot be separated from the interests of the holders of ideological control. Therefore, the educational process is often directed at the development of certain ideologies. Francis Wahono said, if the holder of ideology or the ruler uses a capital system, then education will lead to a market system with business logic (Wahono, 2001: 9). In addition, education is often run with a command system. This model education will produce "robots" that run with the spirit of "origin happy father", "what is the word kyai and teacher" and so on. Indeed, this is a humanitarian threat, one side of education is used as a place to preserve science, tradition and ideology, and on the other hand education is used as a commodity that expects massive investment and profits.

As a result, today many look "fools" not because they do not learn, but rather because there is no comfortable space to think so that they never think. Society is plunged into scientific patent theories that tend to be dry spiritually, manipulative and loaded with certain interests. A society like this is simply fed, fun entertainment but passive or dead. The compartmentalized, stereotypical religious practices that are growing in society against the Islamic ummah are increasingly demoralizing, such as terrorists, not humanists, not pluralists, left behind and the like.

Nestapa and the ice of education (not least Islamic education) above must be ended immediately. Education must be returned to its original khittah, that is, to humanize man with all the potential he has. In this framework, the spirit of Islamic liberation must be the spirit and foundation of ontological, epistemological as well as axiological education.

Among the contemporary Islamic thoughts whose concerns give awareness that Islam has the power of liberation is Asghar Ali Engineer. The construction of engineer thought is not specifically related to the problem of education, but because Islamic education is carried out on Islamic grounds, there is no denying that the thought has relevance and urgency. 


\section{Method}

The method used by the authors in this study is library research. This method the author used because it was to know the thoughts of Asghar Ali Engineer in liberation theology. Collection techniques in this study, first select documents or literature related to research studies from several works of Asghar Ali Engineer. Determining the data source in this study the authors divide into two, namely primary data source and secondary data source. The primary data source in this study is literature related to liberation theology by Asghar Ali Engineer, both in the form of books and other related documents. Secondary sources of data in this study are books that support the goals, methods, and evaluation of Islamic education in the perspective of liberation theology.

Procedures and research stages that will be carried out by researchers in general there are three stages, namely the preparation stage, implementation, reporting. In conducting data analysis, the author will use descriptive analysis. The use of descriptive methods of analysis is useful when researchers will describe data, while explaining it into rational thoughts. Thus achieving a data analysis that has empirical values. Data analysis was conducted to interpret the doctrine of Islam as the religion of liberation in education (considering the thoughts of Asghar Ali Engineer).

\section{Discussion}

\section{Biography of Asghar Ali Engineer}

Engineer was born on March 10, 1940 in India, with no clear information about his birthplace (Shaleh, 2003: 86). In the history of thought, mainland India has been known as a productive land for the growth of critical and liberal thinking. It was on this plain that great thinkers were born, such as Shah Wali Allah ad-Dahlawi, Sir Sayyid Ahmad Khan, Abul Kalam Azad, and so on. This reality certainly gives influence and ease to engineers to access the thoughts of these figures. Not surprisingly, in the future engineer's thoughts were colored by the thoughts of Muhammad Iqbal and Kalam Azad.

Engineer was the leader of one of the Isma'iliyyah Shia groups of the Daudi Bohras sect, based in Bombay and very serious in liberation movements. His leadership was continued by the $d a^{\prime} I$ of the sect. To be recognized as $d a^{\prime} I$ one must meet ninety-four simplified qualifications in four categories namely education, administrative, morals as well as family and personality. The interesting and important thing put forward in this context is that da'I must appear as the main defender of the oppressed and encourage the struggle against tyranny (Ephfendi, 1993: 6).

Engineers earn a Doctorate in civil technical from Vikram University, Ujain (India). In addition to secular education, he also received a religious education through informal channels from his father. It was his father who taught engineers Islamic sciences such as theology, tafsir, hadith and fiqh. In addition, Engineers also master various languages, such as English Arabic, Urdu, Persian, Hindi and Marathi (Nuryatno, 2001: 7). With mastery of various languages this allows engineers to learn many cultures and explore the sources of science.

As a scientist and thinker, Engineer has also done a lot of quality works. Broadly speaking, engineers' works can be categorized into four areas: (a) on liberation theology, (b) on gender justice, (c) on communalism, and (d) on Islam in general (Nuryatno, 2001: 13). The works of engineers are in the form of books, articles and other writings in the mass media. Among her works can be mentioned include: Islam and Revolution, (1984), Status of Women in Islam (1987), Islam and Liberation Theology (1990), Islam and Pluralism (1999), Reconstruction of Islamic Thought (1999). 


\section{Construction of Engineer's Thoughts on Islamic Liberation Theology}

As adherents of Islam, Engineer's thoughts are built on the basis of Islam with the main source of the holy book (Qur'an and Sunnah). He seemed to want to show the public that Islam has dynamic teachings that can be used as a source of reference to construct liberation theology. Al-Khaza'leh (2021) that Islam is a religion that rejects the logic of violence, coercion and oppression. This is one of the special characteristics that distinguish him from liberation thinkers outside of Islam such as Paulo Freire. If nonMuslim thinkers (Westerners in particular) have a tendency to "esve" spirituality so that the resulting thought is dry from spiritual touch, then the Engineer's thought is loaded with a spirit of divinity. Although it must be affirmed, that the spirit of divinity is not formatted rigidly, doctrinally and narrowly. On the contrary, the spirit in question is spelled out rationally, grounded and intelligently so as to have real implications for the life of humanity.

When engineers first initiated Islamic liberation theology, he first took an ritual journey into the past to understand the spirit of liberation rolled out by several schools of classical theology, namely the Khawarij, Mu'tazilah, and Shi'ah. According to him, these three schools of theology show the spirit of human liberation from various binding doctrines.

Against the Khawarij School, he considers that the doctrine of collective justice provides inspiration for social justice and equality in Islamic society (Engineer, 1984: 18). With this doctrine, truth and justice must be viewed macro-wise, not just from a narrow, sectarian-leaning angle. In other words, it must be acceptable and recognized by society in general.

In addition to Khawarij, Mu'tazilah by Engineer is also considered as a stream that develops the spirit of liberation. This school is known as the warrior of rational thought, because it rests more on reason than tradition. By Watt, this school is referred to as the "free thinker of Islam" (Watt, 1992: 60). One of the things that caught the attention of the Engineer of Mu'tazilah theology was the doctrine of human freedom in free will. With the spirit of human freedom in doing, it means not justifying the hegemony of certain groups to other groups. If this is developed, human justice, egalitarianism, appreciation of human existence, and so on will be realized.

Another school that engineers see as having a spirit of liberation is the Shi'ah. The principles of tawhid and God's justice in this school are similar to the doctrines emphasized by the Mu'tazilah in his five principles (Glasse, 1999: 387). In his activities, man will only rely on the belief in the oneness of God by being based on a spirit of devotion. In this context, any form of coercion and acidification by any party is contrary to the spirit of tawhid.

By observing the history of some of the etiological circuits above and combined with the depth of his knowledge of Islamic teachings, the Engineer fattened out a brilliant idea of Islamic liberation theology. Thus, the engineer's thinking has a fairly strong base, both from the material and the methodology. His thinking was not uprooted from the roots of history and constructed from the most valid source, scripture.

Engineers explained that Islamic liberation theology does not limit itself to grappling in the purely speculative sphere of thought, but also extends its scope to the problem of praxis (Engineer, 1990: 6).

Engineers believe that Islam has a very rich source of teachings and history and has the potential to be developed into liberating and revolutionary theological teachings. But unfortunately, according to him, Islam has dulled its sharpness as a religion of liberators. One reason is because of the survival of medieval theological dogmas filled with metaphysical and speculative issues. This theological thought is empty and absurd, forgetting the interests of the people, is ahistorical and asocial, and is only familiar with elites and power. For engineers, it is this dogma that has given the legality of oppressive power so far, both coming from the internal and external Islamic world. These dogmas have not only made 
Muslims cruelly squeezed by power, but have also made them rigid and misbehaved in the face of the modernity of the times (Salim, 2010).

What praxis means here refers to a combination of reflection and action, theory and practice, as well as faith and charity. Faith and charity in liberation theology are two sides in the same coin. Through praxis, engineers explain, liberation theology can be the most powerful instrument for anticipating society under the grasp of exploitative rulers. It can also inspire them to act with something terrible revolution against tyranny. Thus, theology of liberation is the product of thought followed by praxis for liberation. Because only by being an active human being can the oppressed free themselves from oppression to borrow Paulo Freire's language, "only those who are oppressed, by freeing themselves, can be free from oppressors" (Freire, 1998: 38).

The main purpose of liberation theology is how it can be more meaningful to marginal and weak groups (Munir \&Munafiah, 2018). Engineers asserted that religion could be opium or a revolutionary force. It all depends on how the religion is interpreted and used. Religion becomes opium when it is in conjunction with the power of the status quo. Religion will only be a "tool of human complaint". In other words, religion no longer gives meaning to the oppressed because it acts more as a condition that does not humanize humans. On the other hand, religion can also be an instrument of change when it is formulated in the form of liberation theology. It is in this formulation that religion can be a very powerful ideological weapon.

According to Putra and Amril (2019) stated that the liberation theology pioneered by Engineer is a creative proposal that links between the importance of a new paradigm in theology that combats oppression in socio-economic structures. This paradigm is motivated by the many phenomena of arrogance of power, injustice, oppression of the weak, restraint on the aspirations of many people, discrimination of skin, nation or sex, accumulation of wealth, violence in the name of religion, and concentration of power in the reality of contemporary society.

Thus, Islamic liberation theology is the theology of struggle, and not the theology of "solace". In this relationship, the Engineer considers that religions, especially Islam, actually have the potential to move their ummah to fight, dynamic, not frozen, flowing continuously against injustice and oppression. Moreover, in the view of Asghar Ali Engineer, Islam is a religion in a technical sense and as a driver of social revolutions that combat oppressive structures. The basic goals are universal brotherhood, equality and social justice (Azizah, 2019).

There are several characteristics of liberation theology initiated by engineers. Agus Nuryatno (2001: 31) inventoried these characteristics based on various writings of Engineers, including:

1. His main concern is about the problems that exist in the world, "now" and "here", and only then the problem of the hereafter. Liberation theology is oriented to respond to praxis and concrete lives, rather than to abstract metaphysical realities. But that doesn't mean ignoring things related to the hereafter.

2. Fight against all pro status quo forces.

3. Have partisanship or become a partisan marginal group and seek to liberate this group of people by giving it a powerful ideological weapon through active participation.

4. Laying down the principle that metaphysical life in the hereafter must be pursued through the life of the world.

5. Prioritizing the problems of praxis in life rather than problems that are abstract-speculative. 
By looking at some of the above characteristics, there is no doubt that practical philosophy becomes the most important part of the ideology of liberating because only with the praxis-active life of human existence gets proportional appreciation.

\section{Reflections of Asghar Engineer's Thought in Islamic Education}

What happened to Islamic education? Why is there such a great suspicion of Islamic education? What sins have been committed by Islamic education? Doesn't education take on a sacred mission: humanizing people, educating, developing critical attitudes, liberating media and preparing students to be able to be in the midst of life? These questions often arise. One reason is because the long story of the failure of Islamic education is more often seen compared to its success.

Indeed, paradoxically with its sacred mission, many signal that Islamic education today is not successful enough. Education is perceived as a place of dehumanization, a process of bullying, the establishment of critical power, the event of oppression, the tool of oppression, the tool of hegemony for the ruling class, even the event of the growth of capitalism. If this perception is correct, Islamic education with all the components involved in it means that it has committed an ontological, epistemological and axiological "sin" at once.

Education is liberation, not oppression. That's what it should be, even if it's the exact opposite. The difference between das sein and das sollen should be of serious concern to thinkers, observers and practitioners of Islamic education. It is time for Islamic education to be returned to the original "khittah" to fit the holy mission it carries out. In this discourse, the Engineer's thoughts on liberation theology can be a consideration.

If you look at some of the characteristics of liberation theology formulated by engineers as described above, it seems relevant to find alternative solutions to the problems of Islamic education today.

First, greater attention to the realities of living in the world, now and here, can serve as a foundation for compiling the curriculum of Islamic education. One of the disadvantages of Islamic education today is its curriculum that tends to be normative-theological, numerating and not grounded, afterlife-oriented. The belief that the hereafter is more important than the life of the world must be interpreted proportionally. It must be remembered, that Islam is a religion that attaches importance to the principle of balance, between the world and the hereafter. The afterlife is actually a continuation of the life of the world.

By referring to the first character of Islamic liberation theology initiated by engineers, the Islamic education curriculum must be structured so that the benefits can be felt by learners in the world, not have to wait later in the hereafter. Normative-theological knowledge must be contextually translated, so as to provide a solution to the problems faced by man. In somewhat extreme language, Islamic education must be carried out by "bringing down God from heaven" to be invited to dialogue by humans on earth. In this way, between heaven and earth it is not separate, but interconnected, even fused.

By referring to the first character of Islamic liberation theology initiated by engineers, the Islamic education curriculum must be structured so that the benefits can be felt by learners in the world, not have to wait later in the hereafter. Normative-theological knowledge must be contextually translated, so as to provide a solution to the problems faced by man. In somewhat extreme language, Islamic education must be carried out by "bringing down God from heaven" to be invited to dialogue by humans on earth. In this way, between heaven and earth it is not separate, but interconnected, even fused.

Second, fight against the pro status quo. Today, education is often used as a means of discussing the ideology, traditions and interests of the ruling elite. In the context of Islamic education, it can be seen from the efforts of certain parties to perpetuate the existence of the embraced school. Actually, fighting 
for the survival of an ideology (school) embraced by someone is natural. In the theory of the development of an ideology, one of the conditions that must exist is a loyal and morally responsible follower of the existence of the ideology. However, the tendency that is seen to the surface is the birth of an attitude of claiming truth (truth claim), what he believes is said to be the truest, shahih, while the beliefs of others are wrong. If education is carried out in the spirit of claiming the truth, then it is pro status quo.

In addition to the pro status quo, the threat of Islamic education is a similar process, in Freire (1998) which is the banking system. In this model of educational concept, a student is a piggy bank and a teacher is its saver. The teacher speaks of reality as if something that is immobile, static and dead. The teacher's job in education is to fill the students with the materials he says, materials that are detached from reality. Practically the practice of education like this is a tool of a system of oppression. Because, this concept has the ability to reduce or even remove the power of student creation and foster an attitude of trust, nerimo ing pandum.

Although not the whole, bank model education is still ongoing in Islamic education. Indicators, among others, teachers/ustadz/kyai/lecturers still often position themselves as the only source of knowledge, authoritarian in learning and unidirectional. The teacher sees himself as a different entity to the student. The usual approach is a narrative approach that directs students to memorize mechanically what the contents of the lesson are told. Thus, the student's task is simply to listen to the teacher's story, record, memorize and repeat the information expressed by the teacher, without understanding what the meaning is contained in it.

In this situation, a teacher has felt successful when he has done a lecture assignment in class and after that the majority of his students get good grades. Some students who don't get good grades are considered failures, stupid, not serious and so on. High grades are given to students who can and are good at imitating or repeating well what the teacher says, even to the point of the semicolon. This becomes an educational catastrophe, as well as a humanitarian catastrophe. Education like this will only make history stop and culture stop. Because, the protégé will eventually switch functions into a robot that loses consciousness, the potential of reason and he moves only based on the instructions of the robot controller.

With regard to such willingness, the spirit to fight various efforts to maintain the status quo, especially in the field of education becomes a necessity. This is where an urgency of Islamic liberation theology thought engineers. Islamic education should be based on the spirit of respecting humans as beings thinking, conscious, potentially and equipped with the right to determine their own life choices.

According Hasan (2021) the system of Islamic education is increasingly losing its quality, efficacy, and functionality in many societies as its curriculum addresses lesser contemporary issues. Therefore, it is very important Islamic education should be designed so that students will be creatively able to construct moral values and theories of science that are functional for their own life problems, not the past experiences of the teacher. The teacher's experience in the past is only important if it is presented again in the learning experience. It is not problem-solving techniques or theories and values taught, but the process of experiential formulation of problem-solving techniques and the choice of value itself. There is no one system of values, theories, customs that prevails throughout the ages for all students in one class. In this framework, teachers are required to have an open attitude, so as not to indoctrinate and support the student community.

Third, side with marginalized communities and encourage them to participate actively. Associated with Islamic education, partisanship to small communities can be translated in the form of providing equal opportunities to all elements of society without having to distinguish social status. Islamic education is also required to be an egalitarian, humanist and non-elitist educational institution. 
During this time, Islamic education seemed to be more in favor of urban communities, rich people, and the ruling class than the people, rural people and the poor. It is in the capitalization of education that most people and fringe people accept the destiny of history. The cost of education is much more expensive than their ability. Only by accidents of history often diverged, few poor people, villagers, could be free from the destiny of history and education.

Phenomena the emergence of superior and quality Islamic education, is actually a breakthrough that needs to be positive appreciation. However, often education in these excellent institutions does not side with the poor. They were investigated first because of their inability to meet administrative requirements that were far out of reach. Finally, quality education is synonymous with education for the bourgeoisie. Poor people must be willing to get an education in institutions that are almost zero facilities.

In the later stages, the poor's fate changes to be almost closed when they can only choose an advanced school with quality of concern. More so, today's culture is still bought by formal culture. That is, a child who graduated from a well-known, favorite, expensive educational institution tends to be considered more qualified, than those who complete their studies from a fringe school. This continues at the level of gaining employment opportunities and participation in life. Substantial aspects, such as scientific qualifications, personality, and work ethic are often not taken into consideration. In this framework, the participation of the poor becomes very limited.

The limitations of poor people's participation in the dynamics of life actually become a form of structural oppression that is very detrimental, because, however, every citizen has the possibility of making a valuable contribution to the life of humanity. However, the possibilities are often closed in line with the growing stereotype that the poor are synonymous with ignorance and backwardness. They seemed destined to be restricted in their movements.

This fact, becomes one of the heavy tasks of Islamic education. Islamic education as an education based on holy teachings (Qur'an and Sunnah) is expected to provide proportional opportunities to all levels of society to receive a proper education and actively participate in all areas of life. For, when the doctrine of the Qur'an affirms that Allah will only give high rewards to the fearer, it is actually an affirmation that man actually has the same opportunities, rights, potentials.

Fourth, liberation theology emphasizes the problem of praxis rather than on abstract-speculative thoughts. If contextualized to the implementation of Islamic education, the emphasis on practice rather than theoretical aspects becomes the most common to learn today. The competency standards set in the curriculum always place emphasis on the three areas, namely cognitive, affective and psychomotor to be integrated in a balance and together. In this regard, the implementation of education is sought to provide experience to learners will not only know theoretically, but also skilled in practicing the knowledge obtained. The idea of 5 pillars of Education Universal formulated UNESCO are learning to know, learning to do, learning to live together, learning to be and learning to believe in God (Mahfud, 2016). In this framework, the task of habituation, practicum, and the like should be the largest part of the teaching and learning process in Islamic education.

Education that only places emphasis on theoretical and moral aspects, has not adequately delivered students to the expected standards of competence. The existence of Islamic religious education as a value education that aims to educate students to understand, live and practice Islamic teachings in everyday life, cannot be realized if the practice of education only dwells on speculative reason.

If you look at the phenomenon of Islamic education curriculum today, the nuance that is quite felt is the pressure on the rational, intellectual, ethical aspects, very few enter the applied area (praxis), skills or technology. However, theoretical knowledge is still needed as an ethical and moral basis, but the praxis aspect must also get a balanced portion in Islamic education. In addition, according to Suyadi \& Widodo 
(2019) the concept of millennialization of Islamic education, substantively, must develop Islamic science, this requires the use of inter-, multi- and trans-disciplinary approaches. This is one of the meanings that can be taken from the spirit of Islamic liberation theology.

\section{Conclusion}

In line with the goal of education to humanize people, foster critical power, provide skills and build student creativity, education must be carried out in a democratic, egalitarian and without oppression. The polarization of oppressed and oppressive societies is absolutely kept away from the practice of education.

Islamic education, which is built on the basis of Islamic teachings, needs to provide sufficient space for the creation of a conducive atmosphere as much as Islam. One of the spirits of Islamic teachings is the liberation of man from all forms of domination, liberation from the waste of aqidah, appreciation of human existence regardless of social, racial, or ethnic stratification. This spirit of Islamic egalitarianism is the most precious treasure that must be divested in the world of Islamic education.

The various thoughts that are questioned by contemporary Islamic thinkers as a form of elaboration of the basic teachings of the Qur'an and Sunnah should also be considered. One of the Islamic thinkers quite concerned in socializing Islam as a teaching of liberation is Asghar Ali Engineer. This engineer's creative thinking has relevance and urgency in efforts to realize Islamic education as a liberator media, from curriculum preparation to learning practices.

\section{References}

Achmadi, (1992). Islam Sebagai Paradigma Ilmu Pendidikan. Yogyakarta: Aditya Media.

Al-Khaza'leh, M. S. (2021). An Outlook of Each of the Islamic Thought and the Contemporary Global Thought on the Human Concept and Rights. Academic Journal of Interdisciplinary Studies. 10(2): 163-175. http://dx.doi.org/10.36941/ajis-2021-0047

Azizah, D. (2019). Teologi Pembebasan Dalam Pendidikan Islam Perspektif Asghar Ali Engineer. Oasis: Jurnal Ilmiah Kajian Islam, 4(1): 30-42. http://dx.doi.org/10.24235/oasis.v4i1.4128

Engineer, A. A. (1984). Islam and Revolution. New Delhi : Ajanta Publication.

Engineer, A. A. (1990). Islam and Liberation Theology : Essays on Liberative Elements in Islam. New Delhi : Sterling Publisher Private Limited.

Freire, P. (1998). Pedagogy of the Opressed. New York : Continum.

Glasse, C. (1999). Ensiklopedi Islam. Jakarta : Raja Grafindo Persada.

Hartoko, D. (1985). Memanusiakan Manusia Muda : Tinjauan Pendidikan Humaniora. Yogyakarta: Kanisius.

Hasan, I. (2021). Challenges of Islamic Education in the Era of Globalization: A Proposed Holistic Solution. International Journal of Academic Research in Progressive Education \& Development. 10(3): 338-349.

Mahfud. C. (2016). The Global and Local Challenges of Islamic Education in Contemporary Indonesia. Scientific Journal of PPI-UKM. 3(2): 50-54.

Munir, M. \& Munafiah, N. (2018). The Liberation Theology Of Asghar Ali Engineer And Its Relevance To Islamic Education Objectives. International Journal On Islamic Educational Research, 2(1): 1-18. https://doi.org/10.14421/skijier.2018.2018.21.01 
Nuryatno, M. A. (2001). Islam, Teologi Pembebasan dan Kesetaraan Gender, Studi Atas Pemikiran Asghar Ali Engineer. Yogyakarta : UII Press.

Putra, R. \& Amril. (2019). Teologi Maut vs Teologi Pembebasan Asghar Ali Engineer. Jurnal A-Aqidah, 11(2): 167-178. http://dx.doi.org/10.15548/ja.v11i2.1420

Qutub, S. (1994). Sebagaimana dikutip oleh Laely Mansur,dalam Pemikiran Kalam dalam Islam. Jakarta : LSIK. Lihat huga, Al-Effendi, A. W. (1994). Masyarakat Tak Bernegara : Kritik Teori Politik Islam. Yogyakarta : LISK.

Rakhmat, J. (1994). Islam Alternatif. Bandung: Mizan.

Salim, H. (1993). Memikirkan Kembali Asumsi Pemikiran Kita. Pengantar, dalam Asghar Ali Engineer, Islam dan Pembebasan. Yogyakarta : LKIS.

Salim, H. H. (2010). Menimbang Teologi Pembebasan Islam: Refleksi Pemikiran Asghar Ali Engineer. Jurnal Orientasi Baru, 19(2): 139-153.

Shaleh, A. K. (2003). Pemikiran Islam Kontemporer. Yogyakarta : Jendela.

Siswanto. (2019). Islamic Moderation Values on theIslamic Education Curriculum in Indonesia: A Content Analysis. Jurnal Pendidikan Islam, 8(1): 121-152. http://dx.doi.org/10.14421/jpi.2019.81.121-152

Suyadi \& Widodo, H. (2019). Millennialization Of Islamic Education Based On Neuroscience In The Third Generation University In Yogyakarta Indonesia. Qudus International Journal Of Islamic Studies. 7(1): 173-202. http://dx.doi.org/10.21043/qijis.v7i1.4922

Wahono, F. (2001). Kapitalisme Pendidikan, Antara Kompetisi dan Keadilan. Yogyakarta: Pustaka Pelajar.

Watt, W. M. (1992). Islamic Philosophy and Theology. Edinburgh: Edinburgh University Press. 